NOTE

\title{
Phage particles infecting branchial Rickettsiales-like organisms in banded carpet shell Polititapes virgineus (Bivalvia) from Galicia (NW Spain)
}

\author{
S. Darriba ${ }^{1}$, M. Ruiz ${ }^{2}$, C. López ${ }^{2, *}$ \\ ${ }^{1}$ Instituto Tecnolóxico para o Control do Medio Mariño de Galicia (INTECMAR), 36611 Vilagarcía de Arousa, Pontevedra, \\ Galicia, Spain \\ ${ }^{2}$ Centro de Investigacións Mariñas (CIMA), 36620 Vilanova de Arousa, Pontevedra, Galicia, Spain
}

\begin{abstract}
Basophilic intracellular prokaryotic-like colonies were observed in the gills of banded carpet shell Polititapes virgineus (= Tapes rhomboides) (Linnaeus, 1767) from a natural bed in Galicia (NW Spain). Light microscope observations suggested the presence of 2 types of colonies, but transmission electron microscopy revealed that these were the same Rickettsialeslike colonies, one infected and the other uninfected by phage particles. This is the first report of the presence of phage particles in Rickettsiales-like organisms in the gills of $P$. virgineus.
\end{abstract}

KEY WORDS: Virus $\cdot$ Prokaryotic organisms $\cdot$ Ultrastructural analysis

\section{INTRODUCTION}

Intracellular prokaryotic organisms such as Rickettsiae, Chlamydiae and Mycoplasma were reported for the first time in marine bivalves by Harshbarger et al. (1977). Rickettsial and chlamydial organisms are prokaryotic organisms, generally intracellular obligate parasites and Gram-negative, belonging to the orders Rickettsiales and Chlamydiales, respectively. Rickettsiae or rickettsia-like organisms have been most commonly reported in bivalves (Fryer \& Lannan 1994, Renault \& Cochennec 1994, Wen et al. 1994, Villalba et al. 1999, Wu \& Pan 2000, Molloy et al. 2001, Hine \& Diggles 2002, Sun \& Wu 2004). Branchial rickettsia-like infections have been associated with mortalities in bivalve populations (Gulka \& Wen Chang 1985, Le Gall et al. 1988, Norton et al.
1993, Villalba et al. 1999, Wu \& Pan 2000, Sun \& Wu 2004).

During a histological survey in a natural bed of the banded carpet shell Polititapes virgineus (=Tapes rhomboides) from Galicia (NW Spain) to search for the cause of a significant recent population decline, we found a high prevalence and density of branchial intracellular prokaryotic organisms, some of which were infected by phage particles. Phages have previously been described hyperparasitizing prokaryotic organisms in cells of some bivalve species (Harshbarger et al. 1977, Buchanan 1978, Meyers 1979, Johnson \& Le Pennec 1995, Wu \& Pan 2000, Molloy et al. 2001, Sun \& Wu 2004).

The purpose of the present study was to investigate the basophilic intracellular prokaryotic-like colonies observed in the gills of Polititapes virgineus in Galicia. 


\section{MATERIALS AND METHODS}

A sample of 30 clams $(45.6 \pm 2.7 \mathrm{~mm}$ long, $21.30 \pm$ $5.33 \mathrm{~g}$ mass) was collected for a histological survey in June 2010. Gills were processed by histological techniques and stained with Harris' hematoxylin and eosin (H\&E) for analysis by light microscopy. The infection intensity of prokaryotic colonies in each clam was calculated from the number of colonies in the gill measured at $1000 \times$ magnification in 10 fields (equivalent area: $0.38 \mathrm{~mm}^{2}$ ). Thirty colonies of each type were measured using the imaging software Cell* (Olympus). To further characterize prokaryotic colonies the following additional staining techniques were used: Gram's Brown and Hopps method, the Pinkerton method for rickettsial organisms, the Ziehl-Neelsen method for acid-fast bacteria and Feulgen methods for DNA. Gills embedded in paraffin blocks and fresh tissue were processed for analysis with a transmission electron microscope (TEM).

\section{RESULTS AND DISCUSSION}

Light microscope observations of H\&E-stained tissues revealed the presence of 2 kinds of branchial intracellular inclusion colonies in all individuals sampled. The most abundant type of colony (Type I) had a granular appearance $(14.87 \pm 4.34 \mu \mathrm{m}$ length; mean $\pm \mathrm{SD}, \mathrm{n}=30$ ) whereas the other (Type II) (15.53 $\pm 4.04 \mu \mathrm{m}$ length, $\mathrm{n}=30$ ) was scarce and had a granular and bacillary appearance, with larger micro-

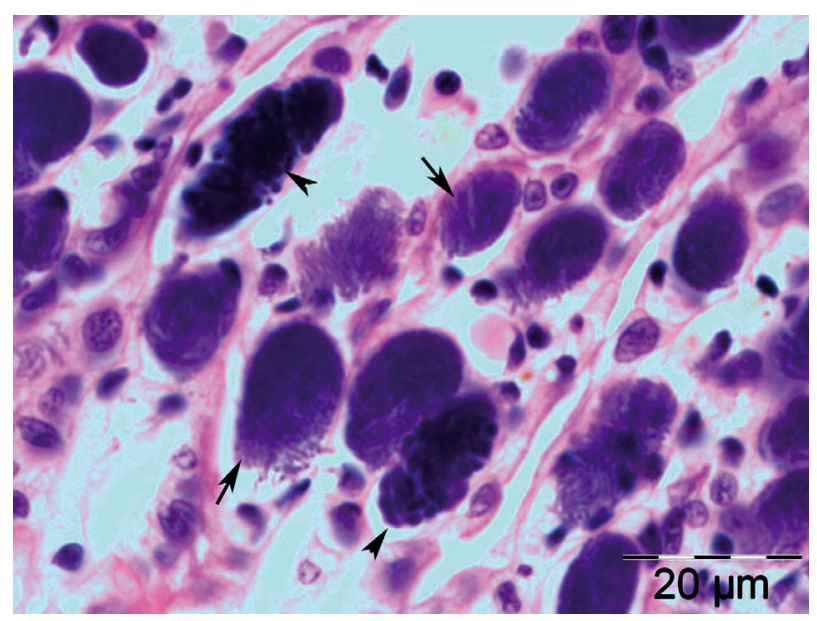

Fig. 1. Light micrograph of a heavily infected gill of Polititapes virgineus with 2 types of intracellular prokaryotic-like colonies: Type I (arrows) and Type II (arrowheads) (H\&E staining). Scale bar $=20 \mu \mathrm{m}$ organisms inside and stronger basophilia (Fig. 1). The Type I colony is similar to those described by Villalba et al. (1999) in the same bivalve species. The mean intensity of Type I colonies was higher $(47 \pm$ 24 colonies per area $\left[0.38 \mathrm{~mm}^{2}\right] ; \mathrm{n}=15$ ) than the mean intensity of Type II colonies $(2 \pm 1$ colonies per area $\left[0.38 \mathrm{~mm}^{2}\right] ; \mathrm{n}=15$ ). Both types of colony were Gram-negative, acid-fast negative and Feulgen positive (with stronger reaction in Type II), and they took on a red colour typical of rickettsial colonies analyzed using the Pinkerton methods; similar results have been reported by several authors (Wen et al. 1994, Gardner et al. 1995, Wu \& Pan 2000).

TEM examination revealed 2 types of intracellular colony inside vacuoles of host cells. Type I colonies were densely packed, composed of pleomorphic prokaryotic organisms measuring up to $2.5 \mu \mathrm{m}$ in length (Fig. 2A). They showed the typical prokaryotic nucleoid and ribosomes distributed randomly. A thin rippled wall and a plasma membrane (electro-dense) separated by a pale layer (electro-lucent) were observed (Fig. 2B). Some colonies exhibited 2 nucleoids and a transverse constriction, suggesting binary fission (Fig. 2B). Similar colonies have been observed by Fries \& Grant (1991), Fries et al. (1991), Villalba et al. (1999), and Hine \& Diggles (2002). Type II colonies were larger (measuring up to $3.5 \mu \mathrm{m}$ ) and infected by apparently icosahedral phage particles with paracrystalline disposition. Phage infection provokes the enlargement of the prokaryotic organism, causing breakage and liberation of virus particles into the cytoplasm of the host cell (Fig. 3). In addition, we occasionally observed prokaryotic organisms both

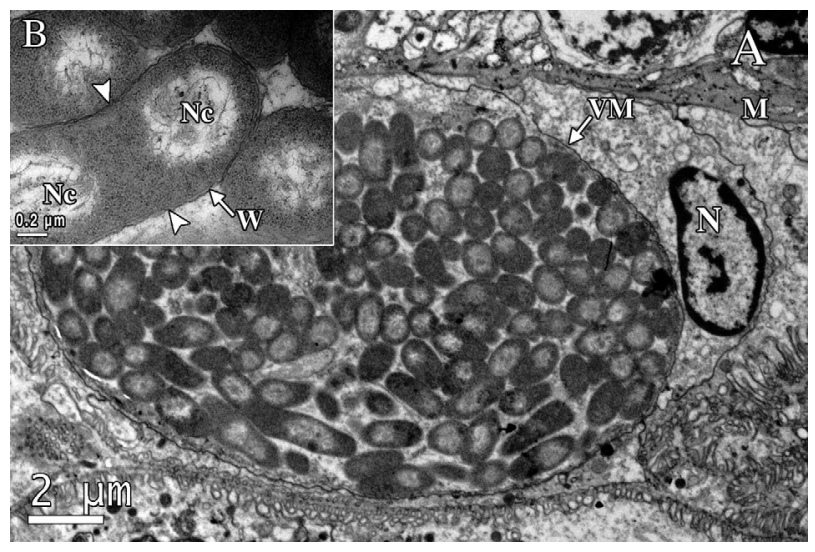

Fig. 2. (A) Ultrathin section of an intracellular colony of Rickettsiales-like organisms Type I in the gill of Polititapes virginieus. N: nucleus of cell host; $\mathrm{M}$ : membrane of cell host; VM: vacuole membrane. (B) Detail of a Rickettsiales-like organism with a transverse constriction, suggesting binary fission (arrowheads). Nc: nuleoid; W: wall. Scale bar $=0.2 \mu \mathrm{m}$ 


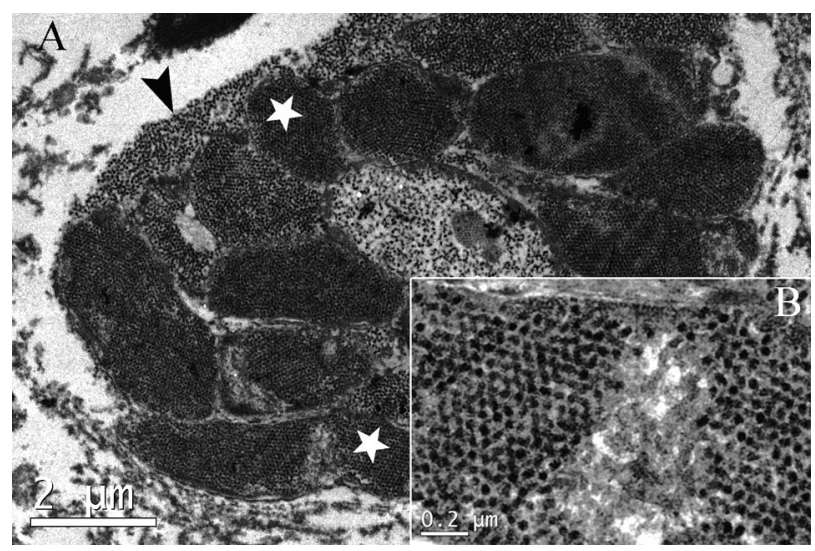

Fig. 3. (A) Ultrathin section of one Type II colony with prokaryotic organisms containing phage particles mostly occurring in paracrystalline arrays (stars) and free phage particles in the cytoplasm of the host cell (arrowhead). (B) Detail of phage particles

infected and uninfected by phages in the same colony.

Rickettsiae and Chlamydiae are commonly distinguished (using electron microscopy) by taking into account their morphology and division system. Chlamydial species are all coccoid and they have a complex developmental cycle (reticulate and elementary bodies), whereas rickettsial species are pleomorphic and replicate by binary fission (Fryer \& Lannan 1994). Few intracellular prokaryotic organisms infecting aquatic animals have been sufficiently characterized for precise taxonomic placement (Fryer \& Lannan 1994). In the case of marine invertebrates, the principal problem in the study of intracellular obligate parasites is the absence of cell lines. Molecular techniques can help to identify these organisms, as in the case of the identification of 'Candidatus Xenohaliotis californiensis' in Haliotis spp. (Friedman et al. 2000).

The terms rickettsia-like and chlamydia-like were used in some reports to refer to intracellular inclusion bodies using only light microscope observations. Nevertheless, without ultrastructural data it is only possible to name these inclusions 'intracellular inclusion bodies' or 'intracellular prokaryotic-like inclusions'.

We consider the branchial intracellular prokaryotic colonies found in Polititapes virgineus to be organisms belonging to the order Rickettsiales, because we observed pleomorphic morphology and only division by binary fission, with an absence of reticulate and elementary bodies.

High prevalence and intensity suggest that these Rickettsiales-like organisms could be related to a mortality episode which caused a decline in the population. More studies are being conducted to study population dynamics and pathology in Polititapes virgineus beds.

Results of ultrastructural observations indicated that the Type II colony, observed by light microscope, corresponded to the same Rickettsiales-like organism infected by phage particles. This was concluded by the observation of 1 colony with both infected and uninfected Rickettsiales-like organisms.

Chlamydial and rickettsial organisms infected by phages have been reported in different bivalve tissues (Harshbarger et al. 1977, Buchanan 1978, Wen et al. 1994, Johnson \& Le Pennec 1995, Comps \& Tigé 1999, Wu \& Pan 2000, Molloy et al. 2001, Sun \& Wu 2004) but not in gills, as in the present study.

Different authors have suggested that the spreading of the pathogenic rickettsial and chlamydial organisms might be controlled by the phage infection; this can infect all the bacteria in a colony, causing obvious damage such as lysis of the host cells (Harshbarger et al. 1977, Comps \& Tigé 1999, Molloy et al. 2001).

Acknowledgements. We thank the technicians at INTECMAR, CIMA and CACTI for their excellent technical assistance. We especially thank F. Febrero and L. Rodríguez for supplying the sample.

\section{LITERATURE CITED}

Buchanan JS (1978) Cytological studies on a new species of rickettsia found in association with a phage in the digestive gland of the marine bivalve mollusc, Tellina tenuis (da Costa). J Fish Dis 1:27-43

Comps M, Tigé G (1999) Procaryotic infections in the mussel Mytilus galloprovinciallis and in its parasite the turbellarian Urastoma cyprinae. Dis Aquat Org 38:211-217

Friedman CS, Andree KB, Beauchamp KA, Moore JD, Robbins TT, Shields JD, Hedrick RP (2000) 'Candidatus Xenohaliotis californiensis', a newly described pathogen of abalone, Haliotis spp., along the west coast of North America. Int J Syst Evol Microbiol 50:847-855

Fries CR, Grant DM (1991) Rickettsiae in gill epithelial cells of the hard clam, Mercenaria mercenaria. J Invertebr Pathol 57:166-171

Fries CR, Grau SB, Tripp MR (1991) Rickettsiae in the cytoplasm of gill epithelial cells of the soft-shelled clam, Mya arenaria. J Invertebr Pathol 57:443-445

Fryer JL, Lannan CN (1994) Rickettsial and chlamydial infections of fresh water and marine fishes, bivalves, and crustaceans. Zool Stud 33:95-107

Gardner GR, Harshbarger JC, Lake JL, Sawyer TK and others (1995) Association of prokaryotes with symptomatic appearance of withering syndrome in black abalone Haliotis cracherodii. J Invertebr Pathol 66:111-120

Gulka G, Wen Chang P (1985) Pathogenicity and infectivity of a rickettsia-like organism in the sea scallop Placopecten magellanicus. J Fish Dis 8:309-318 
Harshbarger JC, Chang SC, Otto SV (1977) Chlamydiae (with phages), Mycoplasmas, and Rickettsiae in Chesapeake Bay bivalves. Science 196:666-668

Hine PM, Diggles BK (2002) Prokaryote infections in the New Zealand scallops Pecten novaezelandiae and Chlamys delicatula. Dis Aquat Org 50:137-144

Johnson MA, Le Pennec M (1995) Association between the mollusk bivalve Loripes lucinalis and a Chlamydia-like organism, with comments on its pathogenic impact, life-cycle and possible mode of transmission. Mar Biol 123:523-530

Le Gall G, Chagot D, Mialhe E, Grizel H (1988) Branchial Rickettsiales-like infection associated with a mass mortality of sea scallop Pecten maximus. Dis Aquat Org 4: 229-232

> Meyers TR (1979) Preliminary studies on a chlamydial agent in the digestive diverticular epithelium of hard clams, Mercenaria mercenaria (L.) from Great South Bay, New York. J Fish Dis 2:179-189

Molloy DP, Giamberini L, Morado JF, Fokin SI, Laurelle F (2001) Characterization of intracytoplasmic prokaryote infections in Dreissena sp. (Bivalvia: Dreissenidae). Dis Aquat Org 44:203-216

Editorial responsibility: Mike Hine, Fouras, France
Norton JH, Shepherd MA, Abdon-Naguit MR, Lindsay S (1993) Mortalities in the giant clam Hippopus hippopus associated with Rickettsiales-like organisms. J Invertebr Pathol 62:207-209

Renault T, Cochennec N (1994) Rickettsia-like organisms in the cytoplasm of gill epithelial cells of the Pacific oyster Crassostrea gigas. J Invertebr Pathol 64:160-162

- Sun J, Wu X (2004) Histology, ultrastructure, and morphogenesis of a Rickettsia-like organism causing disease in the oyster, Crassostrea ariakensis Gould. J Invertebr Pathol 86:77-86

- Villalba A, Carballal MJ, López C, Cabada A, Corral L, Azevedo C (1999) Branchial rickettsia-like infection associated with clam Venerupis rhomboides mortality. Dis Aquat Org 36:53-60

Wen CM, Kou GH, Chen SN (1994) Rickettsiaceae-like microorganisms in the gill and digestive gland of the hard clam, Meretrix lusoria Röding. J Invertebr Pathol 64:138-142

> Wu XZ, Pan JP (2000) An intracellular prokaryotic microorganism associated with lesions in the oyster, Crassostrea ariakensis Gould. J Fish Dis 23:409-414

Submitted: February 6, 2012; Accepted: June 6, 2012

Proofs received from author(s): August 7, 2012 